\title{
Industrial Policy in Nicaragua: A Case Study of the Textile Industry
}

\section{Rhys Jenkins}

\section{Introduction}

This paper examines the textile industry as a case study of some of the problems facing industrial development and industrial policy in the Nicaraguan context. These are seen as deriving from two main sources, namely the historical legacy of the pre-revolutionary period and the external military and economic pressures on Nicaragua today. This is not to deny the fact that the Sandinista government has committed several policy errors, but to put these in the context of the severe constraints under which such policies must operate.

There have been several macro studies of the Nicaraguan economy which have highlighted the overall costs of US economic and military aggression [Conroy 1985; FitzGerald 1987; Gibson 1986]. There have also been several global studies of the industrial sector in Nicaragua, its development since the Revolution and the problems which it faces [Weeks 1985; Harris 1985; Brundenius 1985, 1987]. The object of the present paper is to examine these issues within the context of a specific industry - textiles - which makes it possible to analyse the precise mechanisms through which the historical legacy of the Nicaraguan economy and the external aggression against Nicaragua influence industrial development and policy.

\section{The Structure of the Nicaraguan Textile Industry}

The textile industry, for the purpose of this paper, has been defined to include those firms which engage in spinning yarn and weaving and knitting cloth and in finishing processes. As can be seen in Table 1, there are a total of 11 firms in operation, all of which belong to the public sector, the Area de Propiedad del Pueblo (APP). Outside the textile industry there are five APP firms producing garments, as well as 44 medium sized firms and 128 small firms in the private sector.

There are two large integrated mills with spinning,

\section{Table 1}

Firms operating in the Textile Industry

\begin{tabular}{|c|c|c|c|}
\hline & $\begin{array}{c}\text { Employment } \\
1986\end{array}$ & $\begin{array}{c}\text { Production } \\
1986 \\
\text { (metres) }\end{array}$ & $\begin{array}{l}\text { Gross Value of } \\
\text { Production } 1985 \\
\text { (mn C\$) }\end{array}$ \\
\hline \multicolumn{4}{|c|}{ Woven Cloth } \\
\hline Fanatex & 1,475 & $8,160,000$ & $1,051.2$ \\
\hline Texnicsa & 1,269 & $5,710,000$ & 757.5 \\
\hline Texlasa & 281 & $3,538,000$ & 114.9 \\
\hline Las $3 \mathrm{~F}$ & 188 & $41,717,000$ & 113.4 \\
\hline Prosan & 341 & $2,877,000$ & 167.1 \\
\hline Nicarao & 255 & 801,000 & 145.7 \\
\hline \multicolumn{4}{|c|}{ Knitted Cloth } \\
\hline Tricotextil & 243 & n.a. & 138.0 \\
\hline Hilanica & 221 & n.a. & 104.7 \\
\hline Nicatex & 130 & n.a. & 53.3 \\
\hline Cotexma & 370 & n.a. & 153.0 \\
\hline Fibratex & 60 & n.a. & 31.2 \\
\hline
\end{tabular}

Sources: Instituto Nacional de Estadisticos y Censos (INEC)

UNIDO, 1987, Tables I.3 and II.1 
weaving and finishing departments, FANATEX and TEXNICSA, each employing more than 1,000 workers. The only other firm to have its own spinning department is TEXLASA, which produces industrial cloth for covering tobacco plants and baling cotton. There are six knitting factories of which one, NICARAO, also has limited weaving facilities. The industry is completed by two specialised producers, PROSAN, producing sanitary and medical products, and LAS $3 F$, making laces and elastic.

The textile industry was established in Nicaragua as an industrial activity in the early 1950s. However, these were relatively minor operations, and the two main manufacturing companies were formed in the 1960s. The industry grew rapidly in the period before the Revolution, averaging eight per cent per annum in real terms between 1960 and 1978. However, production was particularly seriously disrupted during the Revolution, and in 1979 fell to the lowest level for a decade. One of the two largest factories, TEXNICSA, was bombed during the last days of the Somoza regime and did not resume production until 1981. A number of other factories also suffered damage during this period.

It was not until 1981 that production began to recover and it was 1983 before pre-1979 levels were attained. Since 1983 production has grown at an average rate of 11 per cent per annum in value terms, well above the long term growth rate of the 1960s and 1970s. This has been achieved despite considerable difficulties in obtaining supplies of spare parts and needles for knitting machines and numerous other production problems.

Between 1983 and 1986 the textile industry had the third fastest rate of growth of any Nicaraguan industry in real terms, and the largest absolute increase in output in any industry. In fact, the total increase in the value of textile production in this period was greater than the increase in the output of manufacturing industry as a whole - in other words, non-textile industrial output fell while textile production continued to grow rapidly.

As a result of this growth, textile production accounted for more than six per cent of manufacturing value added and over two per cent of GDP by the mid-1980s [UNIDO 1987, Table I.5]. Employment in the textile industry also grew from 3,000 in 1980 to 5,000 in the mid- 1980 s which represented almost 12 per cent of formal sector employment in manufacturing [UNIDO 1987, Table I.7]. It is also clear that the textile industry has accounted for the greater part of increased manufacturing employment in Nicaragua since the Revolution.

It is not only because of its contribution to manufacturing output and employment that the textile industry is a key sector of the Nicaraguan economy today. The current economic and political situation of Nicaragua has led to the government adopting a number of priorities for production in the current (1987) Economic Plan. These are sectors which will generate net savings in foreign exchange, those which produce goods and services for the defence of the country and those that produce basic consumption goods for the mass of the population. Despite the scarcity of external resources, the government has also attempted to ensure the availability of foreign exchange to import parts which are necessary to maintain existing productive capacity and to guarantee resources for investment projects which are due to be completed this year.

The textile industry plays a key role in supplying the armed forces. In recent years about a fifth of the output of the two major firms, FANATEX and TEXNICSA, has gone to the military. It is also obviously a key industry in terms of supplying the basic needs of the mass of the population. Historically, however, it is an industry that has been heavily dependent on imports, as will be seen below, and where there is, therefore, considerable scope for import substitution. In the long term it might also develop as an export industry in view of the local availability of the basic raw material, cotton. Policy towards the textile industry must therefore be a central part of any industrial policy in Nicaragua.

\section{The Historical Legacy}

The agro-export model which dominated the economy of pre-revolutionary Nicaragua created a structure in which the country produced what it did not consume and consumed what it did not produce. Not only did export crops require imports of machinery, fertiliser and pesticides on a major scale, but very little use was made of these crops as inputs into the local industrial sector. At the same time, industry developed on the basis of imported inputs, with 40 per cent of material costs consisting of imports in the 1970s [Weeks 1985:283].

The textile industry provides a classic illustration of the disarticulation between agriculture and industry which characterised the agro-export model. Immediately after the Revolution, less than four per cent of the cotton produced in Nicaragua was used in the local textile industry [UNIDO 1987, Table III.5]. Both cotton growing and textile production were heavily dependent on imported inputs. In cotton production, imports accounted for 60 per cent of the costs of agrochemicals and two-thirds of the costs of machinery [Evans 1987, Appendix 9].

Despite the local availability of raw cotton, the textile industry has traditionally been a heavy user of imported inputs. In part this reflected the lack of integration between the agro-export sector and the 
industrial sector, so that Nicaragua exported raw cotton and imported yarn and polyester to produce cloth. It also reflected the dependence of the textile industry on imports of expensive dyes and chemicals, and on foreign spare parts. As a result, in 1980 imported inputs accounted for over 20 per cent of the gross value of production of woven cloth and over 40 per cent for knitwear [UNIDO 1987, Table I. 10].

The second feature of the historical legacy which influenced the development of the textile industry after the Revolution was the regional import substitution model of indust rialisation within which it developed. The formation of the Central American Common Market in 1960 gave a substantial boost to industrial investment in the area and led to an expansion of intra-regional trade. As a result, a certain pattern of indust rial specialisation emerged within the Common Market. Thus, on top of the lack of integration between agriculture and industry generated by the agro-export model, the regional integration scheme led to a lack of internal industrial integration within each national economy.

In the case of textile production, the main centres were Guatemala and El Salvador, which exported textiles on a significant scale to the rest of the region. Nicaragua, on the other hand, was a net importer of textiles from the rest of Central America. In the 1970s Nicaragua imported cotton and synthetic yarns from Guatemala and El Salvador, and cloth from all four of its Central American partners [CEPAL 1983, Tables 37 and 38].

In common with other experiences of import substitution in Latin America, much of the machinery used to set up the industry was purchased secondhand, largely from the USA. The growth of the textile industry in Nicaragua in the 1960 s coincided with the closure of many US plants in the 1950 s and 1960 s, as a result of the shift in the location of the US industry from New England to the Sunbelt. This machinery, which in many cases is still in operation in Nicaragua, dates from as far back as 1915 , so that the average age of equipment is now 35 to 40 years.

\section{Current Problems}

Although, as was seen above, the Nicaraguan textile industry has performed relatively well in terms of growth in the $1980 \mathrm{~s}$, particularly when compared with the rest of the industrial sector, this is misleading in several important respects. In physical terms, production of woven cloth has been stagnant since 1983, with the growth in output reflecting the expansion of the knitted cloth sector [UNIDO 1987, Table I.4]. In fact, the increase in production in the industry has been brought about largely by the opening of new plants and the extension of existing plants, which reflects the allocation of a significant proportion of new industrial investment to textiles.

The problems of the textile industry are highlighted by its productivity record and the poor quality of the product. Productivity has declined significantly in the 1980s. As Table 2 indicates, output per loom hour fell by about 30 per cent between 1981 and 1985 . Although the estimates presented here are rather crude, they are confirmed by more detailed research on productivity in FANATEX and TEXNICSA currently being carried out at INIES (verbal communication from Aracelly Garcia).

The quality of yarn and fabric produced is also very low. Cloth defects such as NEPS (small entanglements of fibres), thick places and thin places are many times higher than international standards.

\begin{tabular}{|c|c|}
\hline Table 2 & $\begin{array}{c}\text { Machine Productivity in Weaving, } \\
1981,1985 \\
\text { (square metres per loom hour) }\end{array}$ \\
\hline
\end{tabular}

\begin{tabular}{|lrr|}
\hline & 1981 & 1985 \\
\hline FANATEX & 4.42 & 3.86 \\
TEXNICSA & 4.85 & 3.01 \\
TEXLASA & 26.14 & 14.68 \\
NICARAO & 3.61 & 2.70 \\
Industry Average & 5.64 & 3.99 \\
\hline
\end{tabular}

Source: Ministry of Industry (MIND)

There are a number of reasons for the problems which the Nicaraguan textile industry faces. In the first place the industry is technologically backward. With relatively few exceptions, machinery is largely obsolete, requiring costly maintenance, operating at slow speeds and producing sub-standard products. As has already been mentioned, this reflects in part the specific model of import substitution followed in the industry in the 1960s and 1970s. However, even some of the more recent additions of machinery, including both looms and spinning in FANATEX and TEXNICSA, incorporate obsolete technology when compared with equipment available at the time of installation (1983 and 1985/6).

With the exception of the new spinning frames from the Soviet Union installed at TEXNICSA in the early 1980 s, all the spindles in Nicaragua are at least 10 years old, and more than 40 per cent of all spindles are more than 20 years old. Technology is exclusively ring spinning, although there are plans to build a new open end plant in Esteli in the near future. The situation is similar but not quite as marked in weaving. Again the most advanced technology, shuttle-less looms, is not currently in use in Nicaragua. 150 UTA looms imported from Czechoslovakia in 1983 are the most 
recent to be installed, although many of these are not working because of technical problems. Of the remaining looms, more than half are over 20 years old, and the others close to that age.

With the exception of COTEXMA and TRICOTEXTIL, the situation in the knitwear industry is similar to that in spinning and weaving. The industry is made up of a multitude of different makes and types of machinery, usually bought secondhand. Buildings have not been purpose built, and equipment, particularly for the dyeing and finishing of knitwear, is either obsolete or in extremely poor condition.

A second cause of low productivity in the textile industry is the low level of capacity utilisation. Partly because of the age of much of the equipment and partly because of a number of other factors, full utilisation of capacity in Nicaragua is impossible. In FANATEX, for instance, 18 per cent of all spindles were not operating because of a lack of spare parts, 12 per cent of looms and some of the equipment in the finishing section, including both sanforising machines. Similarly in TEXNICSA, about a third of all looms were not operating because of shortages of yarn and other problems. The achieved efficiency rating in weaving in the firm was only 40 per cent compared to the international norm of around 80 per cent. Production in spinning, too, has experienced problems, due to the poor condition of machinery, lack of maintenance personnel and shortages of spare parts, so that output is only about 70 per cent of capacity.

Some of the reasons for low capacity utilisation and failure to meet production targets have already been mentioned. These include the age and general condition of much of the equipment in the industry. This problem is accentuated by the lack of spare parts as a result of shortages of foreign exchange for imports, the age of many machines, which means that spare parts are no longer readily available for them, and the difficulties created by the US trade embargo. A quarter of the looms and almost a third of the spindles in the industry are of US manufacture, as are many other machines. The problems of obtaining spare parts has led to the cannibalising of machine parts in order to keep a part of the capacity in operation.

The low quality discussed above also affects the level of production. For instance, poor quality yarn leading to breakages causes frequent stoppages in weaving, so that looms are stopped for a high proportion of the time.

A further problem is the lack of necessary inputs, particularly yarn. Almost all the yarn for the knitting industry must be imported, and this is not necessarily always available in the quantity and at the time desired. Even in the weaving industry this may also be a problem. TEXNICSA had more than a fifth of its looms stopped at one stage in 1986 because of the lack of yarn.

There are a number of problems to do with labour which have also affected the performance of the textile industry since the Revolution. Absenteeism is generally high, at $18-25$ per cent of the labour force. Although a part of this absenteeism is regarded as justified, being caused by military requirements and other factors, it nonetheless creates production problems. Two companies had relatively low levels of absenteeism of 8-12 per cent and this appeared to be the result of good management and reasonable, although not ideal, working conditions.

Labour turnover is also a major problem in Nicaraguan industry and it is particularly severe in the textile industry. In the first six months of 1986 the average turnover in nine textile firms was 40 per cent of the labour force, double the average for a sample of 40 firms and three times the level recorded in the food industry (Table 3 ). This represents an annual rate of labour turnover of over 80 per cent, and some firms have reported a turnover of 100 per cent a year.

High rates of turnover are again partly a result of defence requirements. However, they have been accentuated by the low level of wages in the formal

Table 3 Labour Turnover in a Sample of Firms in Nicaragua, January-June, 1986

\begin{tabular}{|lccccc|}
\hline & No. of firms & Workers & Hirings & Quits & Turnover(\%) \\
\hline Services & 8 & 37,630 & 5,751 & 6,657 & 17.7 \\
Construction & 10 & 10,922 & 2,924 & 3,707 & 33.9 \\
Textiles & 9 & 3,468 & 1,858 & 1,418 & 40.9 \\
Food & 13 & 3,291 & 330 & 455 & 13.8 \\
Total & 40 & 55,311 & 10,863 & 12,237 & 22.1 \\
\hline
\end{tabular}

Source: Secretaria de Planificación y Presupuesto (SPP), Nicaragua. Plan Economico Nacional, 1987 
sector and the growth of the informal sector. Real wages in the textile industry, as in manufacturing generally, have fallen drastically in recent years. The introduction of the Sistema Nacional de Organizacion de Trabajo y los Salarios (SNOTS) in 1983 was intended to reduce labour turnover by standardising wages for similar work. However, since the SNOTS only applies to the 'official' economy, there has been a problem as a result of the gap between income levels here and in the parallel economy. Thus firms have found it difficult to retain labour in the face of the higher incomes to be earned in informal commercial activities, and this has led to problems of labour shortages in production activities [see Stahler-Sholk 1986 for a fuller discussion of these issues].

The problem has been particularly marked in the textile industry because in addition to the general fall in real wages, the decision to stop payments in kind to workers in 1985 led to a further fall in real income. Such payments dated from before the Revolution, and in both the major textile firms (FANATEX and TEXNICSA) they came to 115 per cent of the average money wage [Stahler-Sholk 1985]. When these payments were halted, FANATEX lost an entire shift of workers.

A further factor which has contributed to the high labour turnover in the textile industry has been the high proportion of female workers in the labour force, particularly amongst the lowest wage categories. Turnover is higher amongst women than men, and there is some evidence that women workers with children have found it difficult to reconcile their domestic responsibilities with the rotating shift system used in the industry [Oficina de la Mujer 1987]. In FANATEX a factory nursery has been set up, but in the rest of the textile industry women workers are forced to make their own childcare arrangements while they are at work.

The Nicaraguan economy suffers from a chronic scarcity of foreign exchange. Between 1980 and 1986 the terms of trade worsened by over a third and export earnings fell by over a half. As a result, in 1986 exports covered only a quarter of total imports [UNIDO 1987, Table I.1]. Foreign exchange shortages have forced the Nicaraguan government to rely largely on credit lines and foreign aid in order to finance imports. In 1986 the textile industry imported a total of over $\$ 10 \mathrm{mn}$ of raw materials, intermediate inputs, machinery and spare parts. The total amount of free foreign exchange allocated to the industry came to less than $\$ 2 \mathrm{mn}$, the remaining $\$ 8 \mathrm{mn}$ being financed by credits, foreign aid and direct barter [MIND, unpublished data from the Rama Textil].

The scarcity of foreign exchange has two major adverse effects. First, it has led to a bureaucratic system of foreign exchange allocation, which makes it difficult to obtain vital inputs and spare parts quickly when they are required. Moreover, since it is often easier to obtain finance for new projects rather than for rehabilitating existing factories and importing spare parts, it creates a bias in favour of major new investments. Secondly, since many inputs are tied to suppliers who are prepared to offer credit or aid, prices paid for imported goods are often high. Thus expensive dyestuffs are bought from two Swiss firms and polyester is imported from the Soviet Union at well above world market prices.

A further problem from which the industry suffers is a low level of technological capability. Currently there are very few textile engineers in Nicaragua and general technical capacity within the industry is low. This may reflect, at least in part, the outflow of technically qualified labour from Nicaragua since the Revolution, although hard evidence on this is not available.

As well as the objective conditions under which the textile industry is forced to operate, the planning system in force in Nicaragua, with its emphasis on physical targets, and the acute shortages, which mean that the pressure to produce the maximum possible output is paramount, reinforce the tendency to neglect quality. In some instances this has led to complaints from consumers regarding the quality of the industry's products, and no doubt contributes to the continued demand for imported clothing.

\section{Industrial Policy for the Textile Industry}

The catalogue of problems listed in the last section may give a sense of hopelessness, suggesting that the historical legacy and the external pressures are such that government policy can achieve very little. However, an objective analysis of the obstacles should not be equated with a counsel of despair, and even in the current difficult situation there are measures which can be taken. In discussing such measures it is necessary to distinguish between short-run measures and those requiring new investment, which can only be implemented in the medium and long term.

There are two major emphases which can be highlighted in the short-term strategy. The first is the need to increase the level of output obtained from existing firms through a programme of rehabilitation. The second is the need to reduce import costs per unit of output in order to conserve scarce foreign exchange.

In the light of low and falling productivity and poor quality in the industry discussed above, the rehabilitation of a number of the existing plants is an immediate priority. Some plants, because of the age of machinery, the conditions of the buildings etc. are clearly not eligible for rehabilitation, but others do have the potential for upgrading. As a first step a detailed company audit would be required to identify the specific improvements that could be carried out. The returns from such rehabilitation are likely to be 
far greater than those from investment in new plant.

In the light of the continued dependence of the industry on imports and the extreme scarcity of foreign exchange, a second priority is to reduce the import costs of the industry. There is some scope for import savings by substituting locally produced cotton for imported polyester in a number of textile products. It may also be possible to reduce the high cost of imported dyes by a thorough search for substitutes and alternative quotations from new foreign suppliers.

In the longer term the prospects for the textile industry will depend crucially on the progress made in establishing peace in the region and the availability of foreign aid for subsequent reconstruction. There is still considerable scope for import substitution in the industry, and new capacity will be required in weaving, knitting and spinning to cover growing domestic demand.

A crucial question for the future development of the textile industry is the balance between import substitution and export promotion. Although the current situation makes it virtually impossible to export textiles, in the longer term this is a realistic possibility. Nicaragua, as a producer of good quality raw cotton should have a comparative advantage in cotton textile products. Initially therefore, new investment should be concentrated on expanding spinning capacity, partly to supply the domestic market, but also with a view to adding greater value to current cotton exports.

If Nicaragua is to take advantage of its potential comparative advantage in textiles, it is not sufficient merely to build up the physical capacity for increased textile production. It is also necessary for a number of complementary policies to be adopted in relation to training, foreign trade, labour and industrial planning. However, if these are implemented there is every reason to expect that Nicaragua could have a thriving textile industry by the end of the century, covering a large part of domestic requirements, and also exporting certain selected products.

\section{Conclusion}

This paper has enumerated a number of problems which face the Nicaraguan textile industry today. Some of these problems, such as the use of backward technology, heavy dependence on imports, and the low utilisation of locally produced cotton are a reflection of the historical legacy of the model of regional import substitution and agro-export growth. These problems have been intensified and amplified by the military and economic aggression against Nicaragua.

The requirements of national defence have contributed to the high levels of absenteeism by withdrawing workers for military service and the reserve. Economic pressures in the form of the US trade embargo have also created problems, making it difficult to obtain spare parts for imported machinery. As was indicated above, a significant part of the capital equipment in use in the industry originally came from the United States, and difficulties in obtaining spare parts has led to machinery being left idle.

Even more significant than the direct effects of external pressures are the indirect effects which result from the general economic situation to which the war and the embargo have contributed. These problems are most evident in the areas of foreign exchange and the labour market. Chronic shortages of foreign exchange are a major obstacle facing any strategy to develop the textile industry in Nicaragua. It has led to reliance on high priced imported inputs for current operations and very limited options for new investment projects. In the labour market, accelerating inflation as a result of the costs of the war has led to an erosion of real wages within the manufacturing sector, contributing to the growth of the informal sector. As a result, textile firms have experienced difficulties in retaining workers with low wages and increasing transport difficulties. High labour turnover has meant that workers do not acquire skills and new workers are continually having to be retrained.

Although the emphasis of this paper has been on the difficulties faced by the textile industry as a result of its historical legacy and external pressures, at least some of the problems have been self-inflicted. There is general agreement that major policy errors have been committed, most notably with the establishment of a new spinning plant at TEXNICSA. It is also true that a peace settlement in Central America would certainly not resolve the problems of the textile industry. A major reconstruction effort would be required to rehabilitate existing plants and to undertake new investment projects, as well as the development of a more coherent policy framework for the industry as a whole.

\section{References}

Brundenius, C., 1985, Estralegia del Desarrollo Industrial en Nicaragua. 1979-84, INIES/CRIES, Cuadernos de Pensamiento Propio, Managua

- 1987, 'Industrial Development Strategies in Revolutionary Nicaragua' in R. Spalding (ed.), The Political Economy of Revolutionary Nicaragua, Allen \& Unwin, London

CEPAL, 1983, Industrializacion en Centroamerica 1960-1980, Estudios e Informes de la CEPAL, 30, Santiago

Conroy, M., 1985, 'External Dependence, External Assistance, and Economic Aggression against Nicaragua', Latin American Perspectives, vol 12 no 2 
Evans, T., 1987, El algodon: un cultivo en debate, CRIES, Cuadernos de Pensamiento Propio, Managua

FitzGerald, E. V. K., 1987, 'An Evaluation of the Economic Costs to Nicaragua of US Aggression: 1980-1984', in R. Spalding (ed.), op cit

Gibson, B., 1986, '(de) Stabilization Policy in Nicaragua', WIDER Project on Stabilisation and Adjustment Programmes and Policies in Developing Countries and the Role of International Financial Institutions, (mimeo)

Harris, R., 1985, 'The Economic Transformation and Industrial Development of Nicaragua', in R. Harris and C. Vilas, Nicaragua: A Revolution under Siege, Zed Press, London
Oficina de la Mujer, 1987, 'Fuerza Laboral Femenina en la Rama Textil Vestuario: Segregacion, Salarios y Rotacion', Cuadernos de Sociologia, 4-5

Stahler-Sholk, R., 1985, Pago en Especie, CRIES, (mimeo) -1986, Empleo, Salarios y Productividad en la Revolucion Popular Sandinista, CRIES, (mimeo)

UNIDO, 1987, The Textile Industry in Nicaragua: Development Prospects and Restructuring Needs, UNIDO Economic Research Services, Vienna

Weeks, J., 1985, 'The Industrial Sector', in T. Walker (ed.), Nicaragua: The First Five Years. Praeger, New York 